DOI https://doi.org/10.15589/znp2021.1(484).2

УДК 629.5.028.3:004.942

\title{
USING OF SPECIAL MODELING'S COMPLEX FOR DESIGNING OF MARINE TETHERED SYSTEM WITH FLEXIBLE LINKS
}

\section{ЗАСТОСУВАННЯ СПЕЦАЛЬНОГО МОДЕЛЮЮЧОГО КОМПЛЕКСУ ДЛЯ ПРОСКТУВАННЯ МОРСЬКИХ ПРИВ'ЯЗНИХ СИСТЕМ З ГНУЧКИМИ ЗВ'ЯЗКАМИ}

\author{
Kostiantyn S. Trunin \\ trunin.konstantin.stanislav@gmail.com \\ ORCID: 0000-0001-6345-6257
}

\author{
К. С. Трунін, \\ канд. техн. наук, доцент
}

Admiral Makarov National University of Shipbuilding, Mykolaiv

Національний університет кораблебудування імені адмірала Макарова, м. Миколаїв

\begin{abstract}
Analysis of design problems in creating of Marine Tethered Systems (MTS) with Flexible Links (FL), on example, Underwater Tethered Systems (UTeS) and Underwater Towed System (UTS), indicates that great theoretical problem and scientific capacity are calculations of FL of MTS. In this connection tasks and creation of function's models of MTS with FL are arise at quasi-stationary and dynamics modes of operation of mathematical models of dynamics description of FL of MTS and MTS with FL, creating of complex for computer modelling of quasi-stationary and dynamics modes of MTS operation. One's of technical problems under in the time is rational choice of accounting loads. Experimental (full-scale) tests to research loads acting on them are prefer in spite of their complicate and labour content. However, these experiments are very expensive and need huge efforts to its organization, prepare and carry out.

The solution of this problem may be creation of Special Modelling Complex (SMC) for designing of MTS with FL which based at the Mathematical Models (MM) and Computer Program (CP) of the dynamics FL of MTS and MTS with FL. In this article are examined problems and theoretical basis for create SMC for designing of MTS with FL on example UTeS. The possibility is shows of it's using for almost all classes of MTS with FL and of modelling possible accident's modes.

SMC allows to carry out modelling experiment not carry out physical experiment. In the time of modelling of different modes 0f work of MTS with FL is possible down to extreme and emergency. These modes highly not simple to made at natural conditions, sometimes this may be dangerous for tugboat 0f MTS, crews and personnel and be able to losses of property at best.

The offered SMC allows:

- to realize the designing process of MTS with FL with necessary properties and parameters;

- to examine different modes of it's operated at real time;

- take into account minimum (prescribed) radius of bend of FL at the cable reel;

- take into account dynamical impact loads at FL;

- take into account the hydrodynamic forces which emerge under lateral vibration of FL in the water current;

- take into account prescribed floatability;

- to work out recommendations of prognosis of possibility loads for designing of MTS with FL and bring up its to engineering appendix.

Key words: Marine Tethered Systems (MTS); Flexible Links (FL); Underwater Towed System (UTS); designing; perfection of designing; mathematical (MM) model of MTS with FL dynamics; Special Modelling Complex (SMC) for designing of MTS with FL.
\end{abstract}

Анотація. Однією з технічних проблем у проєктуванні МПС з ГЗ є раціональний вибір розрахункових навантажень. Експериментальні (натурні) випробування з дослідження навантажень, які діють на елементи МПС, $є$ переважними, незважаючи на їх складність та трудомісткість. Однак такі експерименти є доволі витратними та потребують великих зусиль з їх організації, підготовки та проведення.

Вирішенням такої проблеми може бути створення спеціального моделюючого комплексу (СМК) для проєктування МПС з ГЗ, який базується на математичній моделі (ММ) динаміки ГЗ МПС та МПС з ГЗ.

У статті розглянуто проблеми та теоретичні основи створення моделюючого комплексу для проєктування МПС з ГЗ з використанням ММ та комп’ютерної програми (КП) динаміки ГЗ МПС та МПС з ГЗ на прикладі ПБС. 


\section{СУДНОБУДУВАННЯ №1-2021}

Показано можливість їх використання практично для всіх видів МПС з ГЗ, а також моделювання можливих аварійних режимів роботи.

СМК дає можливість проводити модельний експеримент не звертаючись до фізичного експерименту. При цьому можливе моделювання різних режимів роботи МПС з ГЗ, яка проєктується, як екстремальних, так і аварійних. Такі режими буває дуже складно створити в природних умовах, іноді це може бути небезпечним для судна-буксирувальника (СБ) МПС, екіпажу та персоналу і в найкращому випадку призведе до матеріальних втрат. Запропонований СМК дає можливість:

- здійснювати процес проєктування МПС з ГЗ з необхідними властивостями та параметрами;

- досліджувати різноманітні режими їх експлуатації в реальному масштабі часу;

- враховувати мінімальний (заданий) радіус вигину ГЗ на барабані лебідки;

- враховувати динамічні ударні навантаження в ГЗ;

- враховувати сили гідродинамічної природи, які виникають у разі поперечної вібрації ГЗ у потоці води;

- враховувати задану плавучість ГЗ;

- розробити рекомендації з прогнозування можливих навантажень для проєктування суднових палубних лебідок (СПМ) та довести їх до рівня інженерного додатку.

Ключові слова: морська прив'язна система (МПС); гнучкий зв'язок (ГЗ); підводна буксирувана система (ПБС); математична модель (ММ) динаміки МПС з ГЗ; спеціальний моделюючий комплекс (СМК) для проєктування МПС з ГЗ.

\section{ПОСТАНОВКА ПРОБЛЕМИ}

Виникнення нових завдань в освоєнні Світового океану, морів і внутрішніх водойм вимагає натепер удосконалення конструкцій морських прив'язних систем (МПС) з гнучкими зв'язками (ГЗ). При цьому виникають завдання розробки моделей функціонування МПС з ГЗ у квазістаціонарних режимах роботи, математичних моделей (MМ) опису динаміки ГЗ МПС і МПС з ГЗ, створення комплексу для комп'ютерного моделювання квазістаціонарних та динамічних режимів роботи МПС.

Нині в основі проєктування МПС з ГЗ необхідна наявність нових ММ опису динаміки ГЗ МПС і МПС з ГЗ, які дозволять відповісти на питання проєктування $з$ максимальним урахуванням їх експлуатаційних властивостей в комплексі і виходом на конструктивні характеристики (вдосконалення проєктних розрахунків конструктивних елементів МПС з ГЗ).

3 точки зору механіки МПС являє собою систему, яка об'єднує два різнорідні об'єкти: прив'язний об'єкт (судна-носія СН та ПА), який може розглядатися як абсолютно тверде тіло, і ГЗ - систему з розподіленими параметрами. При цьому ММ включає: математичну модель Г3; математичні моделі тіл, які 3'єднуються ГЗ на їі кінцях; рівняння, які описують динаміку тіл як граничні умови для ГЗ.

Аналіз різних класів МПС з ГЗ показав, що наявні натепер конструкції мають завищені масо-габаритні показники і матеріалоємність, що впливає на водотоннажність і тактико-технічні характеристики (ТTX) СН ПБС і веде до збільшення експлуатаційних витрат, зниження конкуренції на ринку таких конструкцій i, зрештою, до зниження прибутків від реалізації таких конструкцій, а значить і розроблених проєктів МПС з ГС. Від властивостей металоконструкції залежить довговічність і надійність роботи суднових палубних механізмів (СПМ) МПС, тому під час проєктування особливу увагу необхідно звертати на вдосконалення конструктивних форм і методів їх розрахунку, на економію металу за одночасного забезпечення надійності, довговічності, зручності обслуговування і ремонту. Рішення такої проблеми дозволить також більш рентабельно використовувати енергетичну установку СН МПС, а також обсяги суднових приміщень, в яких розміщуються компоненти МПС. Важливим натепер є економія матеріальних ресурсів, тому що завищені габарити СПМ або ГС ведуть до підвищеної витрати палива, наприклад, для головної енергетичної установки (ГЕУ) СН, збільшення потужності ГЕУ СН і т.П., тобто йдеться не про мінімізацію використовуваних коефіціснтів запасу міцності, а повну відмову від їх використання в конструкторських розрахунках МПС.

Динамічна модель може бути представлена у вигляді інтегральних рівнянь, передавальних функцій, а в аналітичній формі - залежності фазових координат або вихідних параметрів технічного об'єкта від часу.

Математичний опис полягає у встановленні зв'язків між параметрами процесу і виявленні його граничних і початкових умов, а також у формалізації процесу у вигляді системи математичних співвідношень, що характеризують досліджуваний об'єкт (наприклад, технологічний процес функціонування ПБС). Математичний опис складається на основі матеріальних та енергетичних балансів, а також фізичних законів, що визначають перехідні або будьякі інші специфічні особливості процесу.

На наш погляд, таку проблему дозволив би вирішити спеціальний моделюючий комплекс (СМК), що дає можливість здійснювати процес проєктування МПС з ГЗ на базі ММ і комп’ютерної програми (КП) моделювання динаміки ГЗ МПС та МПС з ГЗ. 


\section{АНАЛІЗ ОСТАННІХ ДОСЛІДЖЕНЬ І ПУБЛІКАЦЙ}

Аналіз проєктних завдань під час створення МПС, наприклад, ППС іПБС (підводних прив' язних системППС, підводних буксируваних систем - ПБС та ін.) показує, що значну теоретичну складність і наукоємність набувають розрахунки ГЗ МПС $[1 ; 2]$. Багато дослідників відзначають, що аналітичні методи нині не можна вважати досить алгоритмічними, рішення нових завдань динаміки ГЗ потребує докладання істотних зусиль і витрат часу під час здійснення математичних обчислень. Найбільш перспективним при цьому вважається застосування чисельних методів.

Є велика кількість літератури, присвяченої вивченню поведінки ГЗ у різних середовищах, галузях діяльності. Цьому присвятили свої праці М.М. Александров, Л.С. Астахов, Г.О. Берто, В.С. Блінцов, Б.А. Бугаєнко, Н.І. Виноградов, В.І. Сгоров, І.Б. Іконніков, В.Е. Магула, T.I. Фоссен, Г.К. Хаген, Д. Фенг та ін.

В [3] В.I. Сгоровим розглянуто порядок виконання робіт під час проєктування ПБС. Відзначається, що просторова структура будь-якої гідродинамічної схеми ПБС визначається розташуванням гнучких механічних або електромеханічних зв'язків (буксирно-кабельної частини - БКЧ), що забезпечують механічний, енергетичний та інформаційно-керуючий зв'язок елементів підводної системи - взаємну і з буксирувальником. Конструктивні параметри буксирів зумовлені гідродинамічною схемою ПБС, прийнятою відповідно до технічного завдання на їі проєктування. Насамперед вони залежать від поглиблення Y, швидкості буксирування $v_{0}$ і кривої тягових зусиль буксирувальника $\mathrm{T}=\mathrm{T}(\mathrm{v})$. У разі визначення цих параметрів вагоме значення мають також характеристики тяглових лебідок і спуско-підйомних пристроїв СН (буксирувальника). Модель опису ГЗ ПБС не дає можливості визначити режими маневрування МПС, що призводять до вібрації поганообтічних ГЗ у потоці.

У розвитку ППС останніх десятиліть, як відзначає Н.І. Виноградов та ін. [1, с. 12], проявляються тенденції до розширення діапазонів припустимих режимів їх використання: швидкостей руху, заглиблених підводних апаратів (ПА) та умов впливу зовнішнього середовища (ступеня хвилювання моря, швидкості течії, ухилів дна, прозорості морської води і т.п.). Вони також відзначають, що незважаючи на функціональне i конструктивне різноманіття сучасних ППС, їх розробники стикаються з низкою подібних проблем і потребують розробки загальних підходів до їх вирішення. Найбільш суттєвою особливістю динаміки ППС, що ускладнює іï порівняно з відомою теорією руху в рідині і газі автономних твердих тіл, вони вважають необхідність врахування впливу ГЗ як системи з розподіленими параметрами.

У статті Дакуі Фенг та ін. «Новий метод проєктування підводної буксируваної системи» [4] розглянута гідродинамічна модель буксируваної системи.
Модель буксируваного кабелю в цій роботі заснована на методі Аблоу і Шехтера. У цій статті пропонується спосіб створення буксируваної системи. Основне рівняння вирішується 3 використанням чисельного методу Рунге-Кутта 4-го порядку для стабільного кабелю. Результати обчислень близькі до виміряних.

У дисертації Ховер Франца Стефена «Розрахунок динамічних рухів і напруженості в підводних буксируваних кабелях» [5] розглянуто матричний метод для аналізу системи позиціонування для визначення динамічної реакції ПБС. Використано еквівалентну лінеаризацію і теорію малих збурень, модель хитавиці буксируваного тіла. Два основні спрощення є загальними: малі збурення та еквівалентна лінеаризація. У першому випадку динамічні прогини вважаються малими рухами від статичної конфігурації, форма яких відома. Така модель не дає можливості описувати динаміку ГЗ за великих переміщень ГЗ у складі МПС.

У дисертації Сюзанни Д. Ранмутугали «Комп`ютерне моделювання та дослідження підводних дволанкових і багатоланкових буксируваних систем» [6] зроблена спроба вирішення проблеми опису руху ПБС. Описано тривимірну динамічну комп'ютерну модель, розроблену для вивчення дволанкової ПБС шляхом моделювання кабелів окремо та їх динаміки. Цей підхід також дозволяє моделювати послідовні і паралельні конфігурації ПБС з декількома буксируваними тілами. Кабельна система змодельована з використанням відмінного підходу трьох ступенів свободи, потім використані шість ступенів свободи підводних буксируваних тіл у відповідних місцях кабельної системи. Моделювання кабелю як суцільного середовища і виведення швидкості хвилі напруги представляє його як дискретну модель. Ця модель не дає можливості визначати резонансні режими розтягання ГЗ та максимальні навантаження на ГЗ для оцінки його міцності в процесі маневрування СН та ПА.

У роботі Ши-кун Панга та ін. «Аналіз стану руху буксируваної частини підводної буксируваної системи транспортного засобу при розгортанні троса» [7] досліджено вплив буксируваного троса перемінної довжини на рух допоміжного буксируваного транспортного засобу. Застосовується вдосконалений метод Лагранжа. Описано рух частин буксирного кабелю фіксованої довжини і на етапах розгортання. Використаний метод зосереджених мас з побудовою кінетичної моделі дволанкової ПБС. Конфігурація буксирного троса і характеристика руху допоміжного буксируваного транспортного засобу розраховувалися для різних швидкостей буксирування i розгортання. Однак виникає велика похибка апроксимації ГЗ, ніж з використанням функцій Ерміта. У моделі розглянуто змінну кількість елементів ГЗ. Модель ГЗ тривимірна, але результати отримані для двомірної моделі. Пружність ГЗ врахована.

У статті Вей-кай Цюань, Чжу-ін Чжан та ін. «Геометрично точне формулювання для тривимірного чисель- 


\section{СУДНОБУДУВАННЯ №1-2021}

ного моделювання пуповини в глибоководній системі POB» [8] розглянуто кабель змінної довжини. Під час аналізу руху буксируваних тіл використовуються метод Лагранжа і метод зосереджених мас. Під час аналізу ГЗ використовується змінна кількість елементів.

У статті Бредлі Дж. Бакхема та ін. «Динаміка й управління буксируваної підводної системи», ч. 1: розвиток моделі» [9] розглянуто динаміку буксируваного транспортного засобу і буксируваного об'єкта. Для систем, в яких маса буксируваного засобу порівняна з масою буксирувального засобу необхідно враховувати їх загальну динаміку. Розроблено модель, яка призначена для пошуку мін, використано наближення зосередженої маси для буксируваного транспортного засобу в зв'язку з нелінійними чисельними моделями керованого буксирного судна.

У статті Ф.С. Ховер, М.Ф. Грозенбо і М. Тріантафіллу «Розрахунок динаміки руху і напруг у буксирних підводних тросах» [10] матричний метод аналізу системи розширено для обліку динамічної реакції буксируваної системи. Ключовим $є$ використання методу еквівалентної лінеаризації і малих збурень, кутів нахилу буксирного тіла. Розглянуто два приклади: перший використовує фундаментальні обмеження для пасивної компенсації тяги, а другий стосується використання плаваючих зв'язків для динамічного розвантаження. ГЗ моделюється в диференціальному наближенні (у разі малих збурень форми ГЗ). Така динамічна модель $є$ двовимірною без урахування згинальної жорсткості ГЗ, без проміжних елементів ГЗ.

Наявні методи розрахунку і проєктування або є спрощеними і не враховують дійсні навантаження і характер навантаження ГЗ МПС або є досить складними і громіздкими для конструкторів-проєктантів, в зв'язку з чим вимагають значних витрат часу для їх виконання.

Аналіз наявних моделей динаміки ГЗ МПС показав, що в більшості моделей елемента ГЗ у МПС розглядають динаміку ГЗ за відносно малих переміщень і вигинів, що свідчить про актуальність розробки ММ динаміки руху елемента Г3, що дозволяє враховувати великі переміщення ГЗ у складі МПС.

Необхідно відзначити, що дотепер комплекс, який дозволяв би описувати динаміку ГЗ МПС і МПС з ГЗ, поки не створено, про що свідчить огляд наявної літератури. $€$ тільки окремі спроби опису динаміки деяких елементів МПС з ГЗ: гнучких трубопроводів [11], опис процесу динамічного моделювання буксируваної кабельної системи з використанням центрального позиціонування кінцевих елементів і простого інтегрування [12], рух і ступінь деформації гнучкого шлангу ППС [13], аналіз параболічної частини профілю підводного буксирного кабелю [14] та ін.

\section{META CTATTI}

Метою цього дослідження є обгрунтування можливості створення спеціального моделюючого комп- лексу (СМК) для проєктування МПС з ГЗ шляхом використання розроблених ММ і комп'ютерної програми (КП) опису динаміки ГЗ МПС та МПС з ГЗ з урахуванням їх експлуатаційних характеристик.

\section{ВИКЛАД ОСНОВНОГО МАТЕРІАЛУ}

\section{1. Наявні методи розрахунків і просктування} МПС 3 Г3

Згідно 3 єдиною системою конструкторської документації (ЄСКД), проєктування нового виробу складається з таких стадій, як [15]:

- складання технічного завдання;

- розрахунок технічної пропозиції;

- розробка ескізного проєкту;

- підготовка робочої конструкторської документації (РКД), проведення нормоконтролю, патентної і метрологічної експертизи;

- виготовлення та випробування дослідного зразка;

- коригування робочого проєкту та випуск настановчої партії виробу;

- перевірка, узгодження, внесення змін, затвердження і передача документації до відділу головного технолога.

Більш змістовно порядок виконання робіт під час проєктування МПС на прикладі ПБС та етапи такого розрахунку докладно наведені в [15, с. 38-40].

Як зазначається в $[1 ; 3 ; 16]$, натепер немає єдиної теорії проєктування МПС з ГЗ (надводних, підводних (буксируваних і прив'язних), стаціонарних і дрейфуючих, яка би враховувала всі істотні фактори експлуатації ГЗ і достовірно дозволяла їх проєктувати.

На рис. 1 наведено схему проєктування МПС з ГЗ.

Процес проєктування починається зі з'ясування призначення МПС (відповідь на питання: для чого створюється система, де, коли і в який час вона буде використовуватися). Формулюються вимоги до МПС (надійність, корисна вантажопідйомність, тривалість автономної дії та ін.).

Потім формулюються обмеження, що накладаються особливостями морського середовища (стан моря, сила вітру, гідростатичний тиск, вплив морських організмів, корозійне руйнування і т.п.). Здійснюється вибір типу МПС (поверхнева, заглиблена, одноякірна, багатоякірна і т.п.). Уточнюється конструктивний тип системи і виконується оцінка механічних навантажень. Тут же формулюються обмеження бюджетного (оцінка фінансових витрат) і матеріально-технічного характеру (розробляються заходи щодо матеріально-технічного забезпечення використання МПС). Всі ці етапи пов'язані з передескізним та ескізним проєктуванням системи. Після цього переходять до робочого проєктування системи і виготовлення дослідного зразка. Це система проєктування, яка склалася.

Пропонується метод вдосконалення проєктування МПС з ГЗ з використанням СМК [15, с. 40-44]. 


\section{2. Розвиток наявних методів просктування} МПС

Найважливішим елементом проєктування будь-якої технічної системи натепер є необхідність розробки концепції. Детально концепція вдосконалення проєктування (КСП) описана в [15, с. 38]. КСП МПС з ГЗ як невід'ємна частина процесу проєктування МПС з ГС полягає у створенні комплексної моделі вдосконалення проєктування МПС з ГЗ. Це дозволяє враховувати внутрішні та зовнішні чинники середовища, які впливають на експлуатацію МПС. Можливий також облік нових властивостей ГЗ МПС, які раніше не враховувалися.

У разі здійснення проєктування МПС з ГЗ за допомогою СМК з'являється можливість отримати достовірні результати вже на ранніх стадіях дослідного проєктування. При цьому зменшуються всі види витрат, враховується специфіка експлуатації МПС (внутрішніх і зовнішніх факторів середовища).

На рис. 2 представлена укрупнена схема вдосконалення проєктних завдань: методів проєктування МПС з ГЗ. Спочатку залежно від типу МПС дається опис процесу функціонування МПС. Потім створюється ММ функціонування МПС. Формування множини варіантів структур системи буде залежати від цілей і завдань, які виконуватиме проєктована МПС.

\section{3. Спеціальний моделюючий комплекс} (СМК) для проєктування МПС 3 ГЗ

Запропонований СМК грунтується на розроблених ММ динаміки ГЗ МПС і МПС з ГЗ [2; 17-19; 20] і КП опису динаміки ГЗ МПС (і МПС з ГЗ) [21; 22]. Він дозволяє: удосконалити наявні методи розрахунку і проєктування МПС з ГЗ і довести їх до рівня інженерного додатку, досліджувати різні режими експлуатації практично всіх класів МПС [23-25], отримати значення сил, що діють на ГЗ (і в ній) і робочі органи суднових лебідок [26], оцінити реальні руйнуючі зусилля в ГЗ і МПС. Це дає можливість також розробити рекомендації з прогнозування можливих навантажень для проєктування їх елементів, зменшити масо-габаритні характеристики суднових палубних пристроїв.

СМК дозволяє проводити модельний експеримент, не звертаючись до фізичного експерименту. При цьому можливе моделювання різних режимів роботи проєктованої МПС з ГС, аж до екстремальних і аварійних [27]. Такі режими вельми непросто створити в природних умовах, а іноді це може бути просто небезпечним для судна-буксирувальника (СБ) МПС, екіпажу та персоналу і приведе в кращому випадку до матеріальних втрат.

СМК є свого роду тренажером для конструкторапроєктувальника. Різні варіанти можуть записуватися і зберігатися, створюються і накопичуються бази

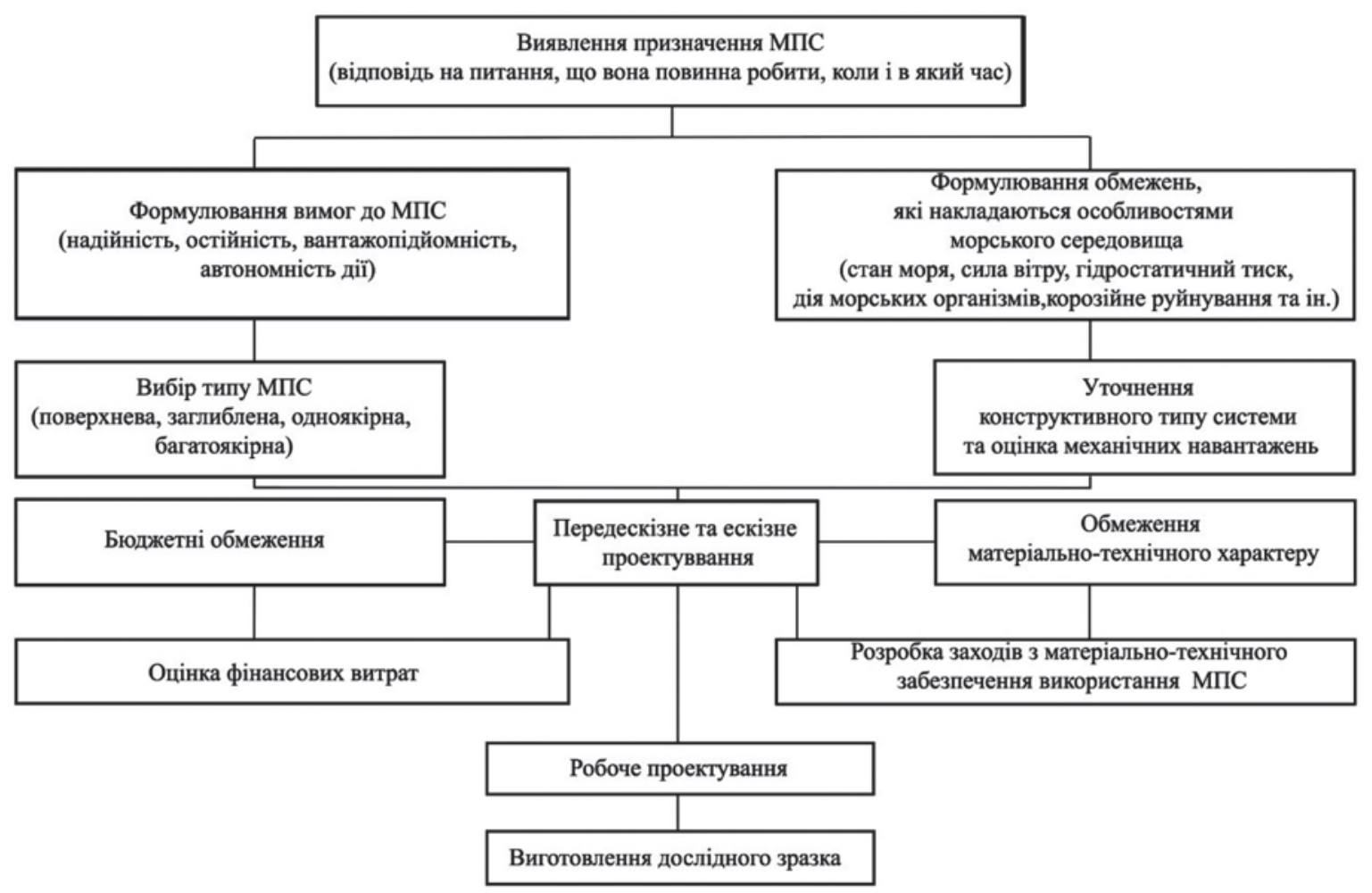

Рис. 1. Схема проєктування МПС з ГЗ 


\section{СУДНОБУДУВАННЯ №1-2021}

даних (БД) різних МПС. При цьому інформація отримується не $з$ фізичного експерименту, а з модельного уявлення про фізичну реальність.

Такий підхід використовується в тих випадках, коли реальні експерименти утруднені через фінансові або фізичні перешкоди або можуть призвести до непередбачувано небезпечного результату.

Такий СМК дозволяє отримати достовірні інженерні рішення вже на ранніх стадіях проєктування (у разі розробки аванпроєкту, технічного завдання та технічного проєкту).

На рис. 3 наведена схема процесу проєктування МПС з ГЗ з використанням СМК на прикладі ПБС. Нижче наведені прийняті скорочення.

Тривимірна модель МПС з ГЗ (ММ динаміки ГЗ i МПС з Гз) пов'язана з базами даних як МПС, так і їі компонентів (СБ, КЛ, СПП, КБ, БПА, ПЕіУ). Особливість використання такої ММ у разі проектування полягає в тому, що МПС з ГЗ проєктується фактично як єдине ціле: зміна будь-якого параметра компонента МПС призводить до автоматичної зміни пов'язаних 3 ним параметрів і об'єктів аж до креслень, специфікацій, візуалізацій, графіка проєктування і т.п. [15].

Оригінальність розробленої ММ динаміки ГС МПС і МПС з ГС полягає в тому, що вона дозволяє в реальному масштабі часу в динаміці за різних параметрів ГЗ і МПС визначати граничні параметри (можливості) досліджуваного (або заданого) ГЗ для визначених СН і ПА.

Отримані ММ динаміки ГЗ МПС і МПС з ГЗ [2; 17-19; 20] дозволили розробити СМК, який дає змогу під час проєктування здійснювати:

- врахування конкретних умов експлуатації ГС МПС і уточнення проблеми зовнішніх сил на базі досвіду та модельного експерименту, наукових досліджень;

- аналіз параметрів морського хвилювання і різних аспектів експлуатації;

- дослідження технологічних процесів використання ГЗ у морських умовах;

- оцінка можливих аварійних ситуацій і вживання заходів з виходу з них;

- обгрунтований вибір критеріїв міцності елементів системи і їх оцінку.

КП моделювання динаміки ГС і МПС з ГЗ розроблена у системі Delphi на основі алгоритму розв'язання системи рівнянь ММ динаміки МПС [21]. Робоче вікно програми на екрані комп'ютера містить вікна для завдання величин параметрів ГЗ та МПС (від 37 до 67) і 4 параметрів алгоритму.

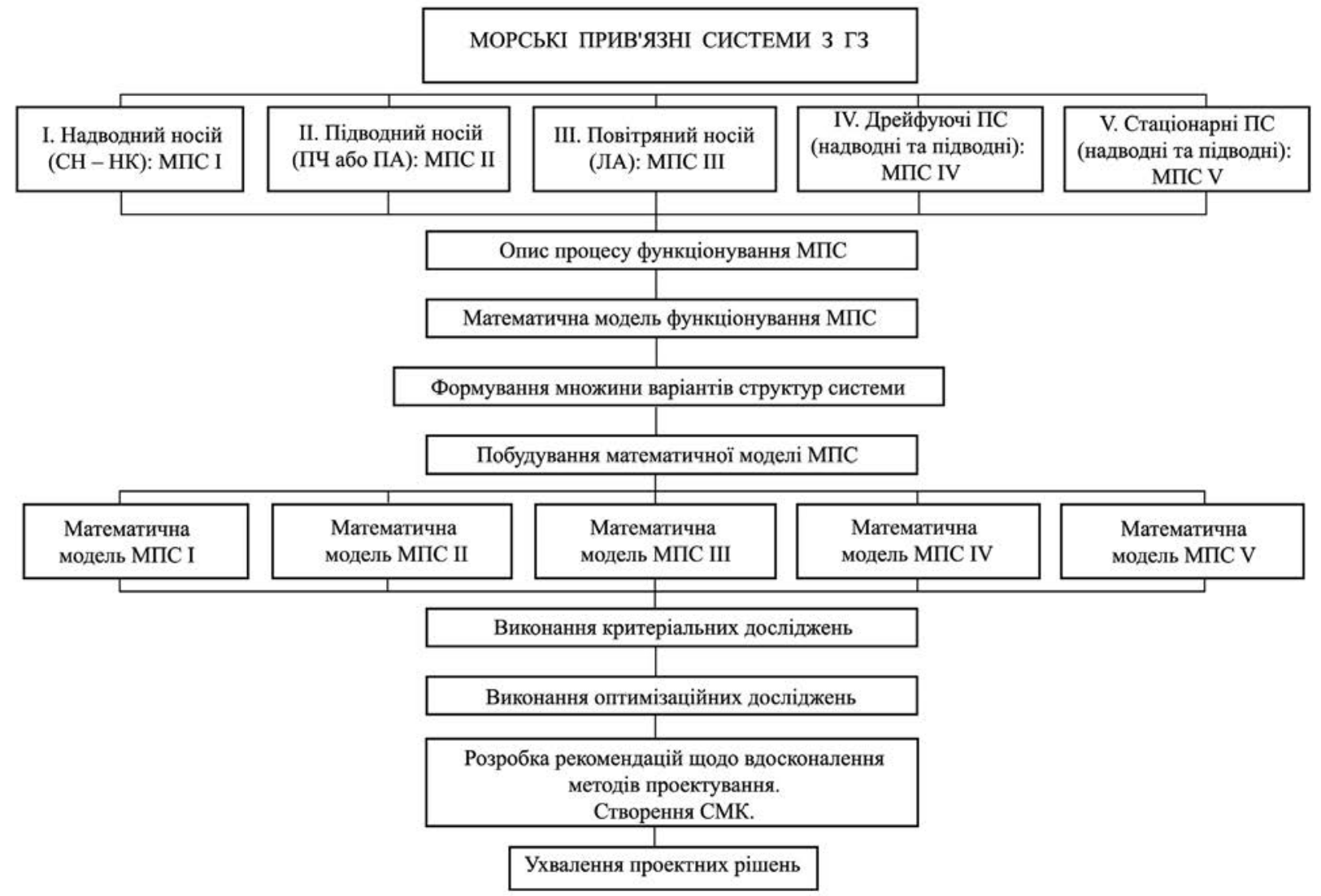

Рис. 2. Схема вдосконалення проєктних завдань: методів проєктування МПС з ГС 


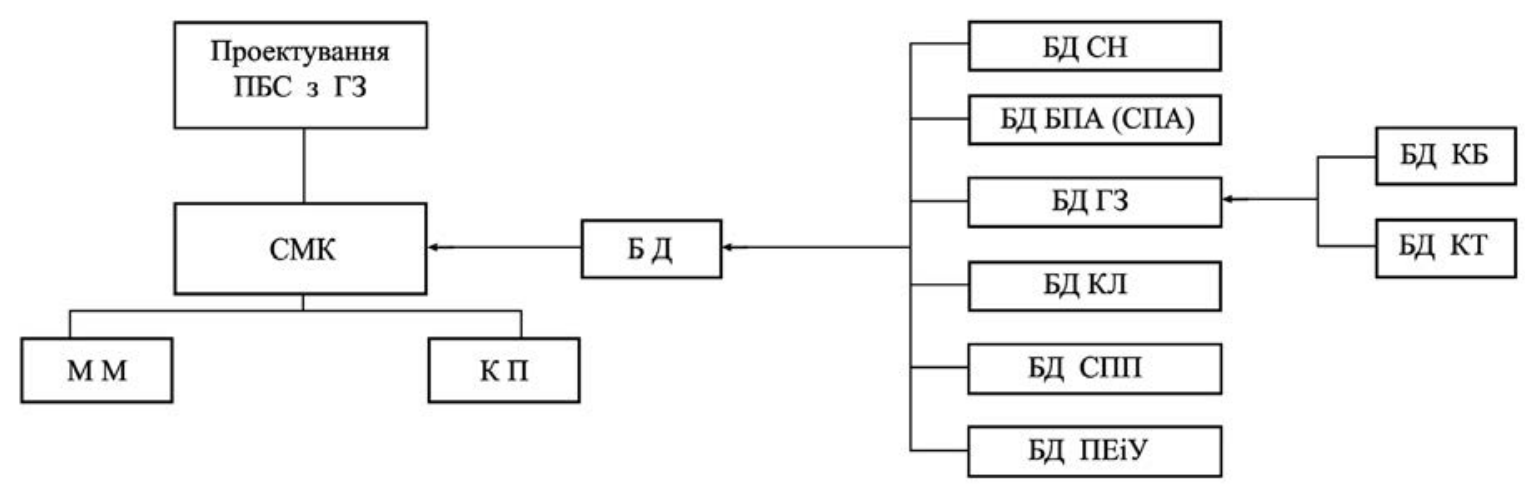

Рис. 3. Процес проєктування ПБС з ГС з використанням СМК Прийняті скорочення на схемі:

ПБС з ГС - підводна буксирувана система з гнучким зв'язком;

СМК - спеціальний моделюючий комплекс;

ММ - математична модель опису динаміки ПБС з ГС;

КП - комп'ютерна програма моделювання динаміки ПБС з ГС;

БД - база даних;

БД СН - база даних судна-носія (буксирувальника); БД БПА - база даних буксируваного підводного апарату;

Праворуч від цих вікон коротко записано назву параметрів та їх розмірності. У процесі виконання програми користувач може спостерігати на діаграмах робочих вікон зміну положення вузлів елементів ГЗ, на кінцях якої великими маркерами показані координати СН і ПА, а також зміна сил розтягування ГЗ у вузлах його елементів. Це дозволяє оперативно визначати правильність вибору параметрів МПС у разі заданих режимів руху СН і ПА в умовах морських течій, хвилювання поверхні моря (синя лінія на діаграмах) і взаємодії елементів МПС 3 морським дном.

Тестування КП підтвердило добру збіжність результатів моделювання і натурних експериментів [22]. Практична перевірка дозволяє також вирішувати, чи знаходяться в необхідних межах точності помилки вимірювання, що входять до передумов, і чи прийнятні в такому конкретному випадку зроблені припущення. Точність результату якраз і залежить головним чином від того, наскільки точно за допомогою зроблених припущень може бути відображена реальність, яка моделюється.

Оригінальність запропонованої КП моделювання руху МПС полягає в тому, що вона має резерви для розширення і дозволяє отримувати результати в реальному масштабі часу, моделювати різні режими роботи МПС з ГЗ, використовувати іiі для опису динаміки різних МПС. Однак така модель буде дуже складна і її використання під час проєктування потребує великих витрат машинного часу. Тому іiі застосовують частіше на заключному етапі проєктування.
БД СПА - база даних самохідного підводного апарату;

БД ГЗ - база даних гнучкого зв'язку;

БД КБ - база даних кабель-буксира;

БД КТ - база даних кабель-троса;

БД КЛ - база даних кабельної лебідки;

БД СПП - база даних спуско-підйомного пристрою; БД ПЕіУ - база даних поста енергетики і управління;

Зроблено спробу наблизитися до використання інформаційних моделей (IM) у процесі вдосконалення проєктування МПС з ГЗ на прикладі ПБС шляхом використання СМК. Його використання передбачає збір і комплексну обробку всіх необхідних даних (конструкторської, технологічної та ін. інформації з усіма іiі взаємозв'язками і взаємозалежностями). При цьому МПС у процесі проєктування розглядається як єдиний об'єкт з усіма його елементами, які мають до нього відношення.

За допомогою СМК знизиться собівартість робіт під час проєктування за рахунок меншої кількості конструкторів-проєктантів (замість бригади проєктантів у 4-5 осіб знадобиться 1-2) і прискоряться терміни проєктування (терміни можуть зменшитися в 3-4 рази) [15]. Вже на ранніх стадіях проєктування це дасть можливість отримати конкретний практичний результат, тому що дозволяє отримати готові результати проєкту, а також знизить наукову трудомісткість виконуваних робіт.

Запропонований метод вдосконалення проєктування МПС з ГС, заснований на ММ динаміки ГЗ МПС і МПС з ГЗ, дозволяє досліджувати різні режими їх експлуатації практично всіх класів МПС, на відміну від наявних методів. Це дозволяє використовувати його як методику для інженерних розрахунків і розробляти рекомендації з прогнозування можливих експлуатаційних навантажень для проєктування елементів МПС з необхідними властивостями і параметрами. Такий метод проєктування МПС дозволяє також відмовитися від використання фізичного 


\section{СУДНОБУДУВАННЯ №1-2021}

моделювання режимів функціонування МПС з ГЗ, пов'язаного 3 проведенням натурних випробувань у відкритому морі.

Отримані результати дозволяють удосконалювати проєктування МПС з ГЗ з урахуванням призначення об'єкта, результатів попередніх наукових досліджень, наявних досягнень у галузі науки і техніки і досвіду проєктування.

\section{ВИСНОВКИ}

Наукова новизна такого підходу полягає в удосконаленні проєктування МПС з ГЗ на основі використання розробленого СМК із застосуванням нових ММ динаміки МПС з ГЗ як теоретичної основи для розробки високоефективних МПС з ГЗ. Уперше пропонується комплексний підхід у проєктуванні МПС з ГЗ, що дозволяє зменшити кількість етапів проєктування МПС ще на стадії дослідного (доескізного) проєктування. В результаті використання СМК відпадає необхідність у використанні наступних етапів проєктування.
Пропонований СМК, заснований на ММ і КП опису динаміки ГЗ МПС (і МПС з ГЗ), дозволяє удосконалити наявні методи розрахунку і проєктування МПС з ГЗ і довести їх до рівня інженерного додатку, досліджувати різні режими експлуатації практично всіх класів МПС, отримати значення сил, що діють на ГЗ і робочі органи суднових палубних лебідок, оцінити реальні зусилля в ГЗ і МПС, зменшити масо-габаритні характеристики суднових палубних пристроїв.

Використання комплексного підходу в проєктуванні МПС з ГЗ з використанням т.зв. підходу «єдиної кнопки», коли під час іiї натискання здійснюється проєктування всієї МПС загалом (здійснюється проєктування не тільки окремих елементів МПС (ГЗ, КЛ, СН та ін.), а всієї МПС як єдиної системи в цілому 3 урахуванням впливу елементів МПС один на одного. Використання такої комплексної системи вдосконалення проєктування МПС з ГЗ дозволить зменшити кількість етапів проєктування МПС (технічного проєкту і т.п.).

\section{REFERENCES}

[1] Vinogradov, N. I. (2000). Privyaznie podvodnie systemi. Prikladnye zadachi statiki i dynamiki [Tethered underwater systems. Applied tasks of statics and dynamics] / N.I. Vinogradov and others, SPb: Publ. of S.-Pb. University, 2000. 324 c.

[2] Blintsov,V. Trunin, K. (2020). Construction of a mathematical model to describe the dynamics of marine technical systems with elastic links in order to improve the process of their design. Eastern-European Journal of Enterprise Technologies. ISSN 1729-3774 /1/9 (103), UDC 629.5.01.001.63, DOI: 10.15587/1729-4061.2020.197358. pp. 56-66.

[3] Egorov, V. I. (1981). Podvodnie buksiruemie systemi: ucheb. posobie [Underwater tower systems]. Leningrad: Sudostroenie, 1981. $304 \mathrm{p}$.

[4] Dakui Feng, Weiwen Zhao, Wubo Pei, Yacheng Ma. (2011). A new method of designing Underwater Towed System, Applied Mechanics and materials, Vol. 66-68, Trans Tech Publications, Switzerland, pp. 125-1255. DOI:10.4028/www. scientific. net/Amm.66-68.1251

[5] Hover Franz Stephen. (1993). Methods of Positioning Deeply-Towed Underwater Cables: Doctoral dissertation. WHOI-9314, AD-A268 917. Retrieved from: https:// apps.dtic. mil/dtic/tr/tulltext/uz/a268917.pdf.

[6] Ranmuthugala, S. D. (2000). Computer Simulation and Investigation of Underwater Two-Part and Multi Tow Systems Submitted in fulfillment of the requirements for the degree of Doctor of Philosophy in Engineering, university of Tasmania Retrieved from: https://epvints.utas.edu.au/1317/whole.raumuthugala Susantha Devaprija2001_thesis.pdf.

[7] Shi-kun Pang, Hong Cheng, Hong Yi, Jing-yang Liu, Jian Wang. Analysis of Motion State of the Tow-part Underwater Towed Vehicle System During Cable Deployment. Retrieved from: https://ieee[plore.ieee.org./abstract/document/8084915.

[8] Quan W., Zhang Z. A geometrically Exact Formulation for Three-Dimensional Numerical Simulation of the Umbilical Cable in A Deep-Sea ROV System. China Ocean Engineering, Vol. 29, No. 2, pp. 223-240. Retrieved from: https://link.springer. com/article/10.1007/s13344-015-0016-0.

[9] Bucham B., Nahon M., Seto M., Zhao X., Lambert C. Dynamics and control of a towed underwater vehicle system, part I: model development. / Ocean Engineering 30 (2003) pp. 453-470. DOI: 10.1016/s0029-801(02)00029-x. Retrieved from: https://www. elsevier.com/locate/oceaneng.

[10] Hover F. S., Grosenbaugh M. A., Triantafyllou M. S. Calculation of Dynamic Motion and Tensions in Towed Underwater cables. / IEEE Journal of Oceanic Engineering, Vol. 19, No. 3, July 1994, pp. 449-457. Retrieved from: https://core.ac.uk/ download/ pdf/4385954.pdf.

[11] Edmans B. D., Pham D. C., Zhang Z.- O., Guo T. F., Sridhar N. and Stewart G. (2019). An Effective Multiscale Methodology for Analysis of marine Flexible Risers. Journal of Marine Science and Engineering. No. 7, 340; DOI: 10.3390/jmse7100340. Retrieved from: https://c:/users/User/Downloads/ jmse-0700340-v2.pdf.

[12] Gangqiang Li, Iian Iian, Zhu Z. H. (2015). Dynamic Modeling of Towed System Using the Nodal Position Finite Element and Symlectic Integration. Conference Paper, May 2015. DOI: 101115/OMAE2015-41253. Conference: ASME 2015 34 th International Conference on Ocean, Offshore and Arctic Engineering, At t. John's, Newfoundland, Canada, Volume 7: Ocean Engineering. Retrieved from: https://researchgate.net/publication/224634680_Dynamics_modeling-and_control_of_a variable_length_remotely_operated_vehicle_tetter.

[13] Kun-Woo Kim, Jae-Wook Lee, Wan-Suk Yoo. (2012) The motion and deformation rate of a flexible hose connected to a mother ship. Journal of Mechanical science and technjlogy 26 (3), 703-710. DOI: 10.1007/s/12206-011-1202-5. Retrieved from: 
[14] Vineet K. Srivastava. Analyzing parabolic profile path for underwater towed-cable. Journal of Marine Science. Appl. (2014) 13: 185-192. DOI: 10.1007/s11804-014-1240-3.

[15] Blintsov, V., Trunin, K. (2021). Improving the designing of marine tethered systems using the principles of Shipbuilding 4.0. Eastern-European Journal of Enterprise Technologies ISSN 1729-3774 No. 1/13 (109), UDC 629.5.01.001.63, DOI: $10.15587 / 1729-4061.2021 .225512$. pp. 35-48.

[16] Ikonnikov, I.B., Gavrilov, V. M., Puzyrev, G. V. (1992). Podvodnie buksiruemie systemi bui neytralnoy plavuchesty [Underwater tower systems and buoys of neutral floating]. SPb: Sudostroenie, $224 \mathrm{p}$.

[17] Trunin, K. S. (2017). Equation of dynamics of flexible link element of Marine Tethered System. Sb. nauk. prats of NUK, No. 1, 18-25. DOI: 10.15589/jnn20170104.

[18] Trunin, K. S. (2017). The mathematical model of two connection elements of flexible links of marine tethered system. Sb. nauk. prats of NUK, No. 2. Pp. 3-10. Retrieved from: http://eir.nuos.edu.ua/xmlui/handle/123456789/2681? show=full DOI 10.15589/jnn20170201 [in Russian].

[19] Trunin, K. S. (2017). Dynamics of Marine Tethered System with flexible link. Sb. nauk. prats of NUK, No. 3, 3-10. DOI: $10.15589 / \mathrm{jnn} 20170301$.

[20] Trunin, K. S. (2019). Flexible links in Marine Tethered Systems. Monography. Nikolaev: Publ. of Torubara E.S.; Publ. "Naval", $536 \mathrm{p}$.

[21] Trunin K. S. (2017). Kompyuternaya model dinamiki morskoy privyaznoy sistemy s gibkoy svyazyu [Computer model of MLS with FL]. [Computer model of the dynamics of a marine tethered system with flexible connection]. Sb. nauk. prats. NUK, No. 4, pp. 3-13. Retrieved from: http://nbuv.gov.ua/UJRN/znpnuk_2017_4_3 DOI: 10.15589/jnn20170401 [in Russian].

[22] Trunin, K. S. (2017). Testirovanie kompyuternoy programmy modeli dinamiki morskoy privyaznoy sistemy s gibkoy svyazyu [Testing of computer program of dynamics model of Marine lash system with flexible links element]. Shipbuilding \& Marine Infrastructure, 1(7), 95-108. DOI: 10.15589/SMI 20170105.

[23] Trunin, K. S. (2018). Determination of complementary tension of towing rope at the impact to it contrary outsider underwater object at arbitrary plase of rope. Shipbuilding \& Marine Infrastructure, No. 2, 93-105. DOI: 10.15589/SMI20180209.

[24] Trunin, K. S. (2017). The three-dimensional nonstationary motion of Marine Tethered System at maneuvering (on example of circulation). Shipbuilding \& Marine Infrastructure, No. 2 (8), 103-114. DOI: 10.15589/SMI20170219.

[25] Trunin, K. S. (2019). The three-dimensional motion of Marine Tethered Systems at example buoy of neutral floating. Shipbuilding \& Marine Infrastructure, No. 1(11), 18-31. DOI: https://doi.org./10.15589/smi2019.1(11).3.

[26] Trunin, K. S. (2020). Designing of deck cable winches of Marine Tethered Systems with of Flexible Links by using of mathematical modelsof description its dynamics. Shipbuilding \& Marine Infrastructure, No. 1(13). pp. 56-66, p. 74. DOI: https://doi.org./10.15589/smi2020.1(1).1. DOI: 10.15587/1729-4061.2020.197358.

[27] Trunin, K. S. (2018) Accident modes of Marine Tethered Systems. Shipbuilding \& Marine Infrastructure, No. 1, $115-126$. DOI: 10.15589/SMI. 2018.01.16.

\section{СПИСОК ВИКОРИСТАНОЇ ЛІТЕРАТУРИ}

[1] Виноградов, Н. И. (2000) Привязные подводные системы. Прикладные задачи статики и динамики / Н. И. Виноградов, М. Л. Гутман, И. Г. Лев, М. З. Нисневич. Санкт-Петербург : Изд-во Санкт-Петерб. ун-та, 324 с.

[2] Blintsov, V., Trunin, K. (2020). Construction of a mathematical model to describe the dynamics of marine technical systems with elastic links in order to improve the process of their design. Eastern-European Journal of Enterprise Technologies. ISSN 1729-3774 /1/9 (103), UDC 629.5.01.001.63, DOI: 10.15587/1729-4061.2020.197358. Pp. 56-66.

[3] Егоров, В. И. (1981) Подводные буксируемые системы : учебное пособие. Ленинград : Судостроение, 304 с.

[4] Dakui Feng, Weiwen Zhao, Wubo Pei, Yacheng Ma. (2011). A new method of designing Underwater Towed System. Applied Mechanics and materials, Vol. 66-68, Trans Tech Publications, Switzerland, pp. 1251-1255. DOI: 10.4028/www. scientific. net/Amm.66-68.1251.

[5] Hover Franz Stephen. (1993) Methods of Positioning Deeply-Towed Underwater Cables : Doctoral dissertation. WHOI-93-14, AD-A268 917. URL: https://apps.dtic. mil/dtic/tr/tulltext/uz/a268917.pdf.

[6] Ranmuthugala, S. D. (2000) Computer Simulation and Investigation of Underwater Two-Part and Multi Tow Systems Submitted in fulfillment of the requirements for the degree of Doctor of Philosophy in Engineering, university of Tasmania URL: https://epvints.utas.edu.au/1317/whole.raumuthugala SusanthaDevaprija2001_thesis.pdf.

[7] Shi-kun Pang, Hong Cheng, Hong Yi, Jing-yang Liu, Jian Wang. Analysis of Motion State of the Tow-part Underwater Towed Vehicle System During Cable Deployment. URL: https://ieee[plore.ieee.org./abstract/document/8084915.

[8] Quan W., Zhang Z. A geometrically Exact Formulation for Three-Dimensional Numerical Simulation of the Umbilical Cable in A Deep-Sea ROV System. China Ocean Engineering, Vol. 29, No. 2, pp. 223-240. URL: https://link.springer.com/ article/10.1007/s13344-015-0016-0.

[9] Bucham B., Nahon M., Seto M., Zhao X., Lambert C. (2003) Dynamics and control of a towed underwater vehicle system, part I: model development. Ocean Engineering 30, pp. 453-470. DOI: 10.1016/s0029-801(02)00029-x. https://www. elsevier.com/locate/oceaneng.

[10] Hover, F. S., Grosenbaugh, M. A., Triantafyllou, M. S. (1994) Calculation of Dynamic Motion and Tensions in Towed Underwater cables. IEEE Journal of Oceanic Engineering, Vol. 19, No. 3, July 1994, pp. $449-457$. https://core.ac.uk/ download/ pdf/4385954.pdf. 


\section{СУДНОБУДУВАННЯ №1-2021}

[11] Edmans, B. D., Pham, D. C., Zhang, Z. -O., Guo, T. F., Sridhar, N. and Stewart, G. (2019). An Effective Multiscale Methodology for Analysis of marine Flexible Risers. Journal of Marine Science and Engineering. No. 7, 340; DOI: 10.3390/ jmse7100340. URL: https://c:/users/User/Downloads/jmse-0700340-v2.pdf.

[12] Gangqiang, Li, Iian, Iian, Zhu, Z. H. (2015). Dynamic Modeling of Towed System Using the Nodal Position Finite Element and Symlectic Integration. Conference Paper, May 2015. DOI: 101115/OMAE2015-41253. Conference: ASME 2015 $34^{\text {th }}$ International Conference on Ocean, Offshore and Arctic Engineering, At t. John's, Newfoundland, Canada, Volume 7: Ocean Engineering. URL: https://researchgate.net/publication/224634680_Dynamics_modeling-and_control_ of_a_variable_length_remotely_operated_vehicle_tetter.

[13] Kun-Woo, Kim, Jae-Wook, Lee, Wan-Su, Yoo. (2012) The motion and deformation rate of a flexible hose connected to a mother ship. Journal of Mechanical science and technjlogy, 26 (3): 703-710. DOI 10.1007/s/12206-011-1202-5. URL: https://www.springerlinc.com/content/1738-49x.

[14] Vineet K. Srivastava. (2014). Analyzing parabolic profile path for underwater towed-cable. Journal of Marine Science. Appl. 13: 185-192. DOI: 10.1007/s11804-014-1240-3.

[15] Blintsov, V., Trunin, K. (2021). Improving the designing of marine tethered systems using the principles of Shipbuilding 4.0. Eastern-European Journal of Enterprise Technologies. ISSN 1729-3774 No. 1/13 (109), UDC 629.5.01.001.63, DOI: $10.15587 / 1729-4061.2021 .225512$. Рp. 35-48.

[16] Подводные буксируемые системы и буи нейтральной плавучести / И. Б. Иконников, В. М. Гаврилов, Г. В. Пузырев. Санкт-Петербург : Судостроение, 1992. 224 с.

[17] Трунин, К. С. (2017) Уравнения динамики элемента гибкой связи морской привязной системы. Збірник наукових прачь НУК, № 1, с. 18-25. DOI: 10.15589/jnn20170104.

[18] Трунин, К.С. (2017). Математическая модель двух связанных элементов гибкой связи морской привязной системы. Збірник наукових пращь НУК, № 2, с. 3-12. DOI: 10.15589/jnn20170201.

[19] Трунин, К. С. (2017) Динамика морской привязной системы с гибкой связью. Збірник наукових прачь НУК, № 3, с. 3-10. DOI: 10.15589/jnn20170301.

[20] Трунин, К. С. (2019) Гибкие связи в морских привязных системах : монография. Николаев : издательство Торубары Е.С.; издательство «Наваль», 536 с.

[21] Трунин, К. С. (2017) Компьютерная модель динамики морской привязной системы с гибкой связью. Збірник наукових пращъ НУК, № 4, с. 3-13. DOI: 10.15589/jnn20170401.

[22] Трунин, К. С. (2017) Тестирование компьютерной программы модели динамики морской привязной системы с гибкой связью. Судостроение и морская инфраструктура, № 1(7), с. 95-108. DOI: 10.15589/SMI20170105.

[23] Трунин К. С. (2018) Определение дополнительного натяжения буксирного троса при ударе по нему встречного постороннего подводного объекта в произвольном месте. Судостроение и морская инфраструктура, № 2, с. 93-105. DOI 10.15589/SMI20180209.

[24] Трунин, К. С. (2017) Пространственное нестационарное движение морских привязных систем при маневрировании (на примере циркуляции). Судостроение и морская инфраструктура, № 2 (8), с. 103-114. DOI: 10.15589/ SMI20170219.

[25] Трунин К. С. (2019) The three-dimensional motion of marine tethered system at example buoy of neutral floating (Просторовий рух морських прив'язних систем на прикладі буїв нейтральної плавучості). Shipbuilding \& Marine Infrastructure. Судостроение и морская инфраструктура, № 1(11), с. 18-31.DOI: https://doi.org./10.15589/smi2019.1(11).3.

[26] Трунин, К. С. (2020) Проектирование судовых палубных лебёдок морских привязных систем с гибкими связями с применением математических моделей описания их динамики. Shipbuilding \& Marine Infrastructure, DOI: https://doi.org./10.15589/smi2020.1(1).1; Судостроение и морская инфраструктура, № 1(13). DOI: 10.15587/ 1729-4061.2020.197358. pp. 56-66, p. 74.

[27] Трунин К. С. (2018) Аварийные режимы морских привязных систем. Судостроение и морская инфраструктура, № 1, c. 115-126. DOI: 10.15589/SMI.2018.01.16.

(C) Трунін К. С. Дата надходження статті до редакції: 09.03.2021 Дата затвердження статті до друку: 23.03.2021 